\title{
Article \\ The Effect of Zinc, Copper, and Silver Ions on Oat (Avena sativa L.) Androgenesis
}

\author{
Marzena Warchoł *D, Katarzyna Juzoń (D, Kinga Dziurka, Ilona Czyczyło-Mysza, Kamila Kapłoniak (D), \\ Izabela Marcińska and Edyta Skrzypek $\mathbb{D}$
}

check for

updates

Citation: Warchoł, M.; Juzoń, K.; Dziurka, K.; Czyczyło-Mysza, I.; Kapłoniak, K.; Marcińska, I.; Skrzypek, E. The Effect of Zinc, Copper, and Silver Ions on Oat (Avena sativa L.) Androgenesis. Plants 2021, 10, 248. https://doi.org/10.3390/ plants10020248

Received: 31 December 2020

Accepted: 22 January 2021

Published: 28 January 2021

Publisher's Note: MDPI stays neutral with regard to jurisdictional claims in published maps and institutional affiliations.

Copyright: (c) 2021 by the authors. Licensee MDPI, Basel, Switzerland. This article is an open access article distributed under the terms and conditions of the Creative Commons Attribution (CC BY) license (https:// creativecommons.org/licenses/by/ $4.0 /)$.
Department of Biotechnology, The Franciszek Górski Institute of Plant Physiology, Polish Academy of Sciences, Niezapominajek 21, 30-239 Krakow, Poland; k.juzon@ifr-pan.edu.pl (K.J.); k.dziurka@ifr-pan.edu.pl (K.D.); i.czyczylo@ifr-pan.edu.pl (I.C.-M.); k.kaploniak@ifr-pan.edu.pl (K.K.); i.marcinska@ifr-pan.edu.pl (I.M.); e.skrzypek@ifr-pan.edu.pl (E.S.)

* Correspondence: m.warchol@ifr-pan.edu.pl; Tel.: +48-12-425-33-01; Fax: +48-425-33-20

\begin{abstract}
Oat (Avena sativa L.) cultivars 'Bingo' and 'Chwat' were used to compare the embryogenesis competence of another culture. Despite the embryo-like structures obtained from both tested cultivars, only 'Chwat' produced green plantlets, which confirmed the cultivar dependency. 'Chwat' produced the highest number of embryo-like structures and green plantlets $(0.7 / 100$ anthers and $0.1 / 100$ anthers, respectively). The embryo-like structure formation also depended on cold pretreatment combined with $\mathrm{Cu}^{2+}, \mathrm{Zn}^{2+}$, or $\mathrm{Ag}^{+}$ion supplementation, which was applied during the tiller pretreatment or added to the induction media. The highest number of embryo-like structures (2.1/100 anthers) were observed on anthers derived from the tillers kept in a 50\% Hoagland medium with the addition of $10 \mu \mathrm{M}$ of $\mathrm{CuSO}_{4}$. In turn, the induction media supplemented with the ions $\mathrm{Cu}^{2+}, \mathrm{Zn}^{2+}$, or $\mathrm{Ag}^{+}$increased neither the number of embryo-like structures nor the green plantlet production compared to the control conditions. However, such ion applications turned out to be most effective when the induction medium was enriched with $25 \mu \mathrm{M}$ of $\mathrm{AgNO}_{3}$ and left to obtain the highest number of embryo-like structures and green plantlets $(0.8 / 100$ anthers and 0.2/100 anthers, respectively). Therefore, more attention should be paid to the possibilities of adjusting the media nutrient composition, as this may be the only way to significantly increase the efficiency of this method.
\end{abstract}

Keywords: androgenesis; green plantlets; pretreatment; $\mathrm{Zn}^{2+}, \mathrm{Cu}^{2+}$, and $\mathrm{Ag}^{+}$ions

\section{Introduction}

Androgenesis is defined as a developmental pathway leading to obtaining a malederived haploid embryos [1]; presently, it is widely used in the production of doubled haploid (DH) plants in commercial breeding systems. This biotechnological method constitutes an alternative to the numerous cycles of inbreeding or backcrossing required to obtain valuable pure lines used in conventional plant breeding [2]. The most common technique of androgenesis is the isolation of intact anthers, and currently the method is used in a number of crop species, including wheat (Triticum aestivum L.), barley (Hordeum vulgare L.), and rice (Oryza sativa L.) [3]. For oat (Avena sativa L.), DH line production via both androgenesis in anther and microspore culture [4-6] as well as distant crossing with maize [7-10] or pearl millet [11] has been used. Unfortunately, the results of the investigation conducted so far indicate that oat is recalcitrant to haploidization; moreover, the process efficiency of this species is strongly dependent on the genotype [6,12]. Sidhu et al. [7] observed frequencies of haploid production with the oat $\times$ maize technique of between $0.8 \%$ and $6.7 \%$ haploid plants per pollinated floret, while the best recoveries reported in anther culture reached up to 30 green regenerants per 100 isolated anthers [5]. Recently, Warchoł et al. [6] noted the $\mathrm{DH}$ production with the highest efficiency at 0.5 plants per 100 anthers for the cultivar 'Akt'. Such a low haploid plant regeneration rate substantially limits the 
incorporation of this technique into breeding programs and makes it economically unfeasible. For this reason, it seems necessary to conduct further research that may contribute to increasing the efficiency of obtaining oat DH plants. Nowadays, more than 250 plant species have been regenerated using the anther culture technique, mainly from Solanaceae, Brassicaceae, and Gramineae. However, many important species—for example, woody plants or Leguminosae-still remain resistant to androgenesis induction [13,14].

Androgenesis, like other haploid inducing techniques, is influenced by several biotic and abiotic factors. The genotype, physiological state, and growth conditions of donor plants; stage of pollen development; pretreatment of flower buds or anthers; in vitro culture medium composition; and physical factors during tissue culture together with their interactions significantly affect the response of anthers in in vitro culture $[15,16]$. The application of suitable physiochemical factors promotes a stress response that arrests microspores or young pollen grains in their gametophytic pathway. The switch from gametophytic to sporophytic routes, named the "development window" by Smykal and Pechan [17], is relatively limited and happens only between the mononucleate and median binucleate stages of microspores [18]. However, modifications of the stress pretreatment [4,19], carbohydrate source $[20,21]$, or growth regulators of culture media $[6,22,23]$ have led to a significant efficiency improvement of both the androgenesis induction and regeneration of haploid plants (HP). Although in most studies little attention has been paid to the micronutrient composition of the media, Kaushal et al. [24] emphasized that the content of macro- or microelements in the induction medium not only provides nutrition to the microspores or directs the pathways of embryo development but may also determine whether or not the androgenesis will be initiated. Among them, zinc and copper have been indicated as more essential for plant growth and development, are included in all tissue culture media, and are also used in cereal androgenesis $[25,26]$. Copper in the culture medium increases the yield of plant regeneration from callus cultures [27] and allows the production of green plantlets [28]. In cereals, copper exhibits a key role during pollen development [29]. Together with zinc, it is involved in many physiological processes, especially in chlorophyll synthesis and photosynthesis [30,31]. Moreover, $\mathrm{Zn}^{2+}$ plays a fundamental role in biochemical cellular processes, such as auxin metabolism and response to oxidative stress [32]. The tissue culture media are usually supplied with zinc sulfate $\left(\mathrm{ZnSO}_{4}\right)$ and copper sulfate $\left(\mathrm{CuSO}_{4}\right)$ in concentrations of $0.1-8.6 \mathrm{mgL}^{-1}$ and $0.03-0.2 \mathrm{mgL}^{-1}$, respectively [33]. However, as heavy metals at high concentrations, these ions might be toxic and mutagenic [34,35]. Demands for these micronutrients seem to be species-dependent, and the optimization of their concentration in the media has led to the improvement of different culture systems. Unfortunately, studies on their influence on calluses, embryo-like structures (ELS), or haploid plant (HP) production in cereals are still very limited. $\mathrm{Zn}^{2+}$ and $\mathrm{Cu}^{2+}$ ions supplemented into the pretreatment solution or induction medium were examined in barley by Wojnarowiez et al. [36], Echavarri et al. [30], and Makowska et al. [37]. A concentration of $\mathrm{Zn}^{2+}$ from 52 to $520 \mu \mathrm{M}$ in the culture medium resulted in the increased growth of rice [38], whereas $10 \mathrm{mM}$ became toxic for tobacco [32]. Another micronutrient used in plant tissue cultures is silver nitrate $\left(\mathrm{AgNO}_{3}\right)$, a very potent inhibitor of ethylene action. Easy water solubility and chemical stability make it very useful in the regulation of morphogenesis in vivo and in vitro [39]. $\mathrm{AgNO}_{3}$ has been shown to be effective in improving somatic embryogenesis and plant regeneration in a number of dicotyledonous species-for example, Punica granatum and Solanum tuberosum [40,41]. It has also been used successfully in cereal crops, such as rice [42], maize [43], pearl millet [44], and barley [45]. Recently, Shahvali-Kohshour et al. [46] reported the positive effects of silver nitrate on the anther culture of strawberry (Fragaria $\times$ ananassa Duch.).

Therefore, to investigate the effect of $\mathrm{CuSO}_{4}, \mathrm{ZnSO}_{4}$, and $\mathrm{AgNO}_{3}$ on the efficiency of androgenesis induction and green plantlet (GP) regeneration, two oat cultivars-'Chwat' and 'Bingo' - were studied. We analyzed the influence of metal ions (i) applied during tiller pretreatment and (ii) supplemented into induction media. According to our knowledge, 
this is the first report where the impact of $\mathrm{Zn}^{2+}, \mathrm{Cu}^{2+}$, and $\mathrm{Ag}^{+}$ions on oat androgenesis has been investigated.

\section{Results}

Tiller pretreatments and induction media compositions were tested in the context of the production of calluses, ELS, and GPs using the anther culture of two oat cultivars'Bingo' and 'Chwat'. The analysis of variance presented in Table 1 shows that callus production depended significantly on the pretreatment and induction medium, while ELS development depended on the cultivar and pretreatment. The number of regenerated GPs was statistically dependent on the tested cultivar.

Table 1. Two-way analysis of variance on the effect of cultivar, pretreatment, and induction medium composition on the number of calluses, embryo-like structures (ELS), and green plantlets (GPs) calculated for 100 anthers.

\begin{tabular}{|c|c|c|c|c|c|}
\hline $\begin{array}{c}\text { Dependent } \\
\text { Variable }\end{array}$ & $\begin{array}{l}\text { Independent } \\
\text { Variable }\end{array}$ & SS & df & $F$ & $p$ \\
\hline \multirow{3}{*}{ Calluses } & Cultivar & 5.610 & 1 & 3.773 & $0.225^{\mathrm{ns}}$ \\
\hline & \multirow{2}{*}{$\begin{array}{l}\text { Pretreatment } \\
\text { Induction } \\
\text { medium }\end{array}$} & 71.118 & 6 & 3.477 & $0.003^{* *}$ \\
\hline & & 55.242 & 6 & 2.356 & 0.034 * \\
\hline \multirow{3}{*}{ ELS } & \multirow{3}{*}{$\begin{array}{l}\text { Cultivar } \\
\text { Pretreatment } \\
\text { Induction } \\
\text { medium }\end{array}$} & 5.184 & 1 & 5.667 & 0.018 * \\
\hline & & 18.542 & 6 & 3.654 & $0.002^{* *}$ \\
\hline & & 5.388 & 6 & 0.946 & $0.464^{\mathrm{ns}}$ \\
\hline \multirow{3}{*}{ GPs } & \multirow{3}{*}{$\begin{array}{c}\text { Cultivar } \\
\text { Pretreatment } \\
\text { Induction } \\
\text { medium }\end{array}$} & 0.407 & 1 & 5.031 & 0.026 * \\
\hline & & 0.971 & 6 & 2.031 & $0.065^{\mathrm{ns}}$ \\
\hline & & 0.158 & 6 & 0.306 & $0.932^{\mathrm{ns}}$ \\
\hline
\end{tabular}

SS—Sum of squares; df-degrees of freedom; F-F-test; $p$-probability of significance; ns-not significant * significant at $p \leq 0.05 ;{ }^{* *}$ significant at $p \leq 0.01$.

Almost nine thousand anthers from 136 panicles were isolated on the induction medium (Table 2). An almost 2.5-fold higher number of calluses were obtained in cv. 'Chwat' compared to cv. 'Bingo'. The first visible observation was an enlargement in the anther size within the first two weeks after isolation (Figure 1A) which preceded the production of calluses in the following weeks of culture. Morphological observations allowed for the extraction of two types of callus: yellow compact, embryogenic (Figure 1B), and white friable, non-embryogenic (Figure 1C). Four weeks of culturing led to ELS formation (Figure 1D). In total, 38 ELS were obtained in both of the tested oat cultivars (Table 2). The highest number of ELS were obtained from cv. 'Chwat' (0.7 ELS/100 anthers) (Figure 1E,F), and only this cultivar produced green plantlets (0.1 GPs / 100 anthers) (Table 1, Figure 1G). Despite all the developed plantlets being green and healthy (Figure 1H,I), they did not survive the colchicine treatment.

Table 2. The effect of the oat genotype on the efficiency of calluses, embryo-like structures (ELS), and green plantlet (GP) production in anther culture. The data show the mean values \pm standard error.

\begin{tabular}{ccccccccc}
\hline Cultivar & $\begin{array}{c}\text { No. of } \\
\text { Panicles }\end{array}$ & $\begin{array}{c}\text { No. of } \\
\text { Anthers }\end{array}$ & $\begin{array}{c}\text { No. of } \\
\text { Calluses }\end{array}$ & $\begin{array}{c}\text { Calluses/100 } \\
\text { Anthers }\end{array}$ & No. of ELS & $\begin{array}{c}\text { ELS/100 } \\
\text { Anthers }\end{array}$ & No. of GPs & $\begin{array}{c}\text { GPs/100 } \\
\text { Anthers }\end{array}$ \\
\hline 'Bingo' & 71 & 4122 & 29 & $0.7 \pm 0.24$ & 5 & $0.1 \pm 0.06$ & 0 & 0 \\
'Chwat' & 65 & 4779 & 70 & $1.5 \pm 0.25$ & 33 & $0.7 \pm 0.10$ & 7 & $0.1 \pm 0.09$ \\
\hline
\end{tabular}



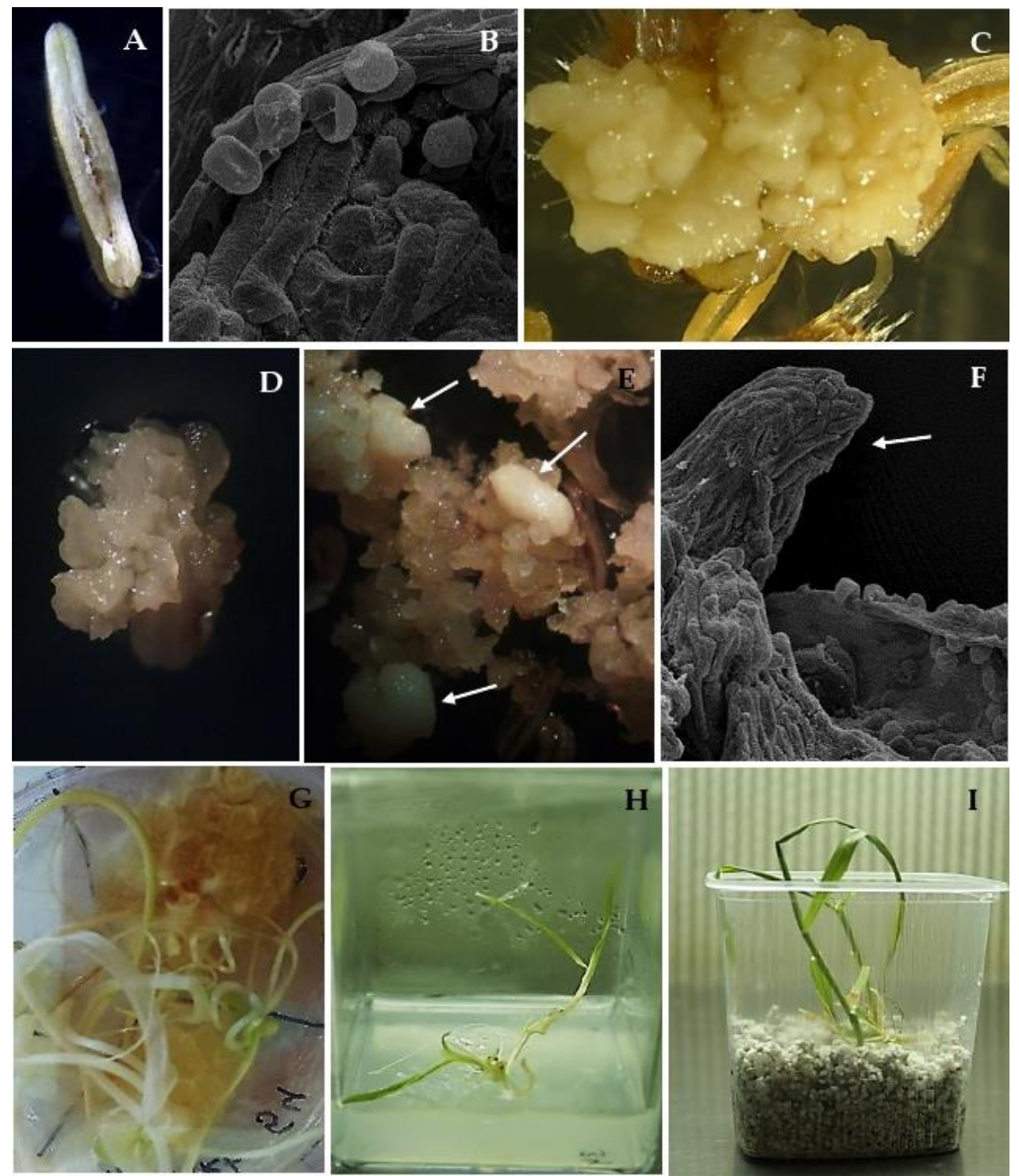

H
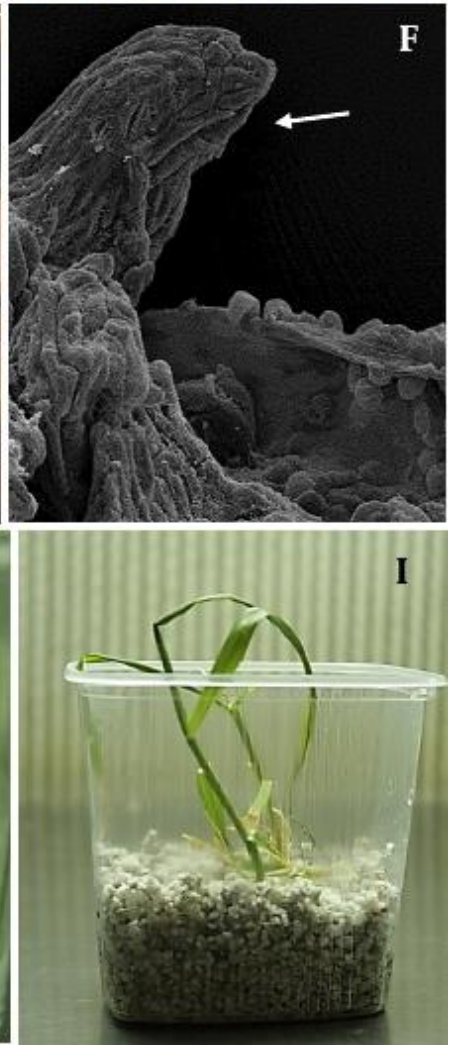

Figure 1. Androgenesis in oat (Avena sativa L.) anther culture: (A) dehisced anther on W14 medium; (B) anther with released microspores; (C) anthers with yellow compact calluses; (D,E) anthers with white, friable calluses with embryo-like structures indicated by arrows; (F) developed embryo-like structure indicated by arrow; $(\mathbf{G})$ regenerated green plantlets on W14 medium with $25 \mu \mathrm{M}$ of $\mathrm{AgNO}_{3}$; (H) green plantlets on MS medium; (I) green plantlets in perlite.

Five of the seven tested pretreatments caused the callogenesis of anthers in both cultivars (Figure 2A). The highest rate of callus production was observed when the panicles of cv. 'Chwat' were kept in 50\% Hoagl. $+20 \mu \mathrm{M} \mathrm{CuSO}_{4}$ or $50 \%$ Hoagl. $+10 \mu \mathrm{M} \mathrm{CuSO}_{4}$ (3.7/100 anthers and 3.6/100 anthers, respectively). The anthers of cv. 'Bingo' did not form calluses when $\mathrm{ZnSO}_{4}$ was added to a $50 \%$ Hoagland medium, regardless of the applied concentration. Similar to callogenesis, the addition of copper ions to the Hoagland medium influenced the effectiveness of androgenesis (Figure 2B). The highest number of ELS were produced when the panicles of cv. 'Chwat' were treated with $50 \%$ Hoagl.+10 $\mu \mathrm{M} \mathrm{CuSO}_{4}$ or 50\% Hoagl. $+20 \mu \mathrm{M} \mathrm{CuSO}_{4}(2.1 / 100$ anthers and 1.8/100 anthers, respectively). Oat cv. 'Bingo' did not form ELS when $10 \mu \mathrm{M}$ of $\mathrm{CuSO}_{4}$, or 90 or $180 \mu \mathrm{M}$ of $\mathrm{ZnSO}_{4}$ were added to $50 \%$ Hoagland medium. Despite the number of GPs not being statistically significantly differentiated and dependent on pretreatment, the majority of GPs formed $(0.6 \%)$ after using $50 \%$ Hoagl. $+10 \mu \mathrm{M} \mathrm{CuSO}_{4}$ (Figure 2C). 

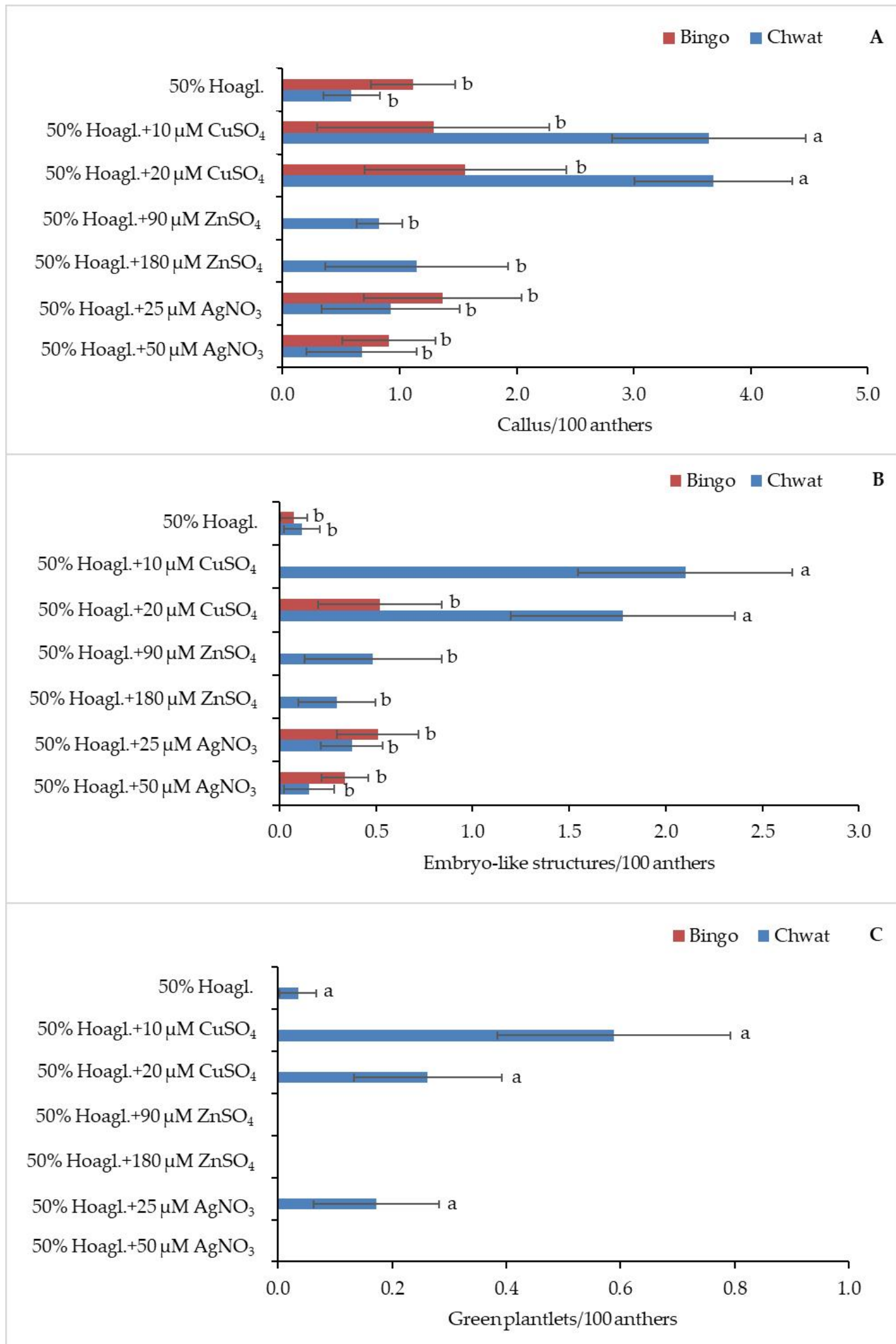

Figure 2. The regeneration response of oat (Avena sativa L.) depending on pretreatment: (A) number of calluses, (B) embryolike structures, and (C) green plantlets calculated for 100 anthers. Bars represent mean values \pm standard error. Significant differences between treatments at $p<0.05$ were marked with different letters.

The effect of the induction medium on androgenesis efficiency is shown in Figure 3. The anthers produced calluses on five tested media. The addition of $\mathrm{AgNO}_{3}$ to the induction 
medium led to obtaining the highest percentage of callogenesis in both tested cultivars; however, the highest efficiency was observed for cv. 'Bingo' on both of the tested concentrations (2.7/100 anthers and 2.6/100 anthers, respectively) (Figure 3A). ELS formation was observed only on two tested media: W14, and W14 supplemented with $25 \mu \mathrm{M}$ of $\mathrm{AgNO}_{3}$.

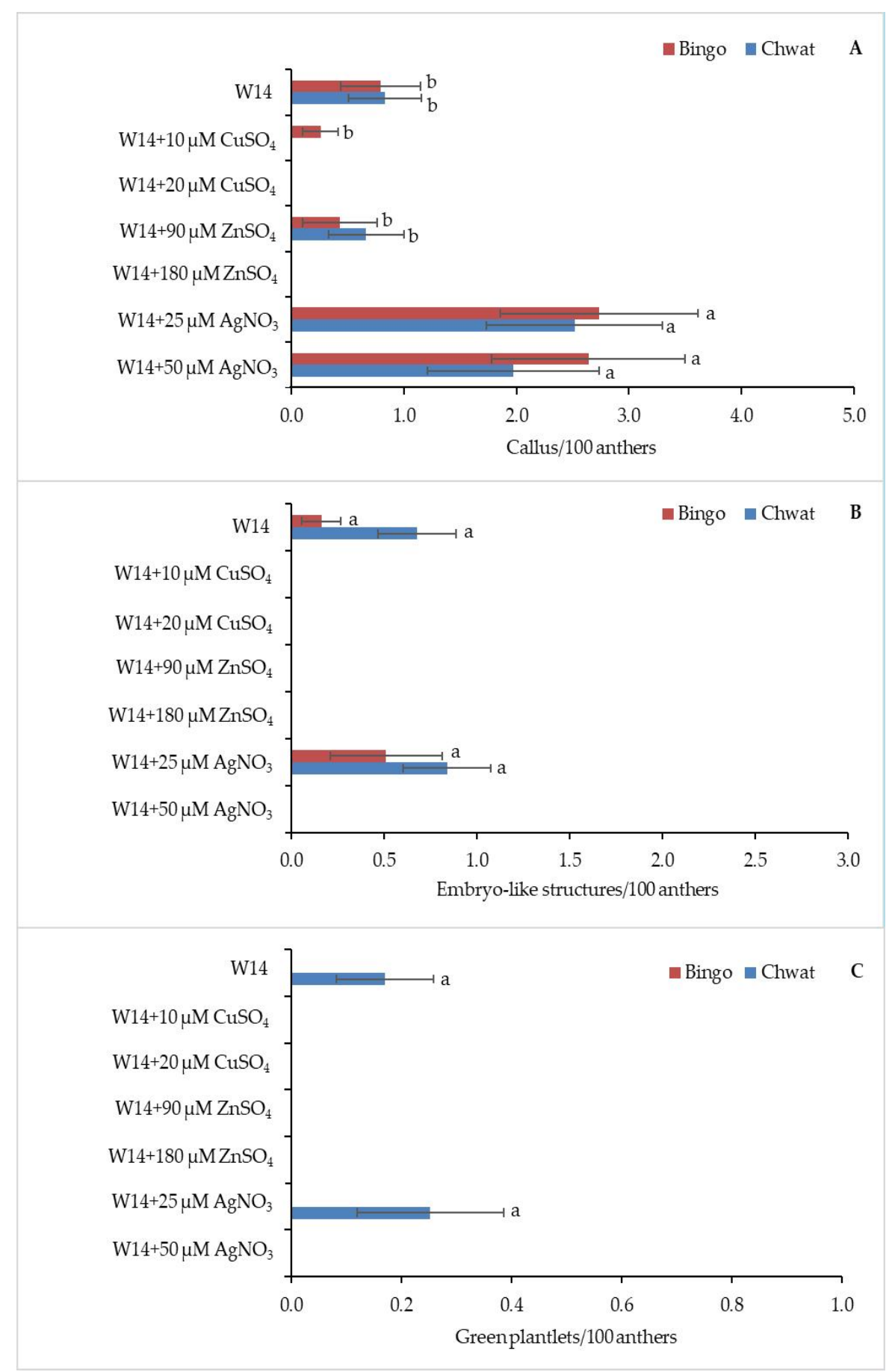

Figure 3. The regeneration response of oat (Avena sativa L.) depending on induction medium: (A) number of calluses, (B) embryo-like structures, and (C) green plantlets calculated for 100 anthers. Bars represent mean values \pm standard error. Significant differences between treatments at $p<0.05$ are marked with different letters. 
Although no statistically significant differences between the used induction media were observed, W14 medium supplemented with $25 \mu \mathrm{M}$ of $\mathrm{AgNO}_{3}$ was more appropriate for androgenesis induction in both cultivars (Figure 3B).

Oat cv. 'Chwat' developed 0.8 ELS/100 anthers, while cv. 'Bingo' produced 0.5 ELS/100 anthers. GP formation was observed on two tested media (W14 and W14+25 $\mu \mathrm{M} \mathrm{AgNO} 3$ ) from ELS produced by cv. 'Chwat' (Figure 3C).

\section{Discussion}

The production of doubled haploids through anther culture forces breeders to improve and stabilize the existing parental line with desired traits in a single year [24]. Seguí-Simarro [1] confirmed that, besides the genotype and the developmental stage of the microspore, the critical factor is the culture conditions, and, in particular, the physical and/or chemical treatment necessary to trigger microspore embryogenesis. Among external factors that can increase the frequency of haploid production, supplementation of the pretreatment solution or induction medium with micronutrients (copper, zinc, and silver) is also postulated. However, there are no reports on the effect of the above-mentioned ions on the androgenic response in oat anther culture; there are a few reports concerning these metal ions on androgenesis of Hordeum vulgare L. [28,30,36,37], Oryza sativa L. [42,47], Triticum turgidum [48], or Fragaria $\times$ ananassa Duch. [46]. It is well documented that in barley anther culture additional $\mathrm{Cu}^{2+}$ supplementation improves the effectiveness of androgenesis. A beneficial effect of copper on barley anther culture was reported by Wojnarowiez et al. [36]. The addition of copper sulfate at $10 \mu \mathrm{M}$ during anther pretreatment and culture increased the anther response by $15 \%$ and the number of green plants by $400 \%$. Regarding androgenesis in oat, our experiment showed that both used concentrations of copper sulfate (10 and $20 \mu \mathrm{M}$ ) added to the medium during pretreatment enhanced callogenesis, as well as ELS and GP development. These results are in accordance with studies in barley anther culture by Jacquard et al. [28]. Typical induction media for androgenesis contain low concentrations of copper, whereas the results of Dahleen [27] showed that its concentration can be up to 100 times higher, and even up to 500 times higher, in recalcitrant barley lines than the one commonly used in culture media. Similar to Makowska et al.'s [37] study in barley culture, we observed a large discrepancy in androgenic reactions to increased $\mathrm{Cu}^{2+}$ amounts depending on the genotype. In oat anther culture, supplementation of this ion during pretreatment only enhanced GP regeneration for cv. 'Chwat'. These observations again confirm the significant effect of the genotype of donor plants on the androgenic response [5].

Our study shows that the addition of 90 or $180 \mu \mathrm{M} \mathrm{ZnSO}_{4}$ in the pretreatment medium did not increase the efficiency of the number of calluses and ELS formation in oat anther culture. The study of Echavarri et al. [30], in turn, showed that the application of $\mathrm{Zn}^{2+}$ ranged from 90 to $180 \mu \mathrm{M}$ in the stress pretreatment, and induction medium significantly increased the number of embryos and green plants, in both anther and isolated microspore cultures. Zinc sulfate used in pretreatment seems to be more beneficial for the cv. 'Chwat', compared to the cv. 'Bingo'. These results could indicate a higher sensitivity of 'Bingo' to this micronutrient, regardless of the concentration. Moreover, enriching the induction medium with a $90 \mu \mathrm{M}$ of $\mathrm{ZnSO}_{4}$ already had a beneficial impact on the callus production for both genotypes. In the above-cited works, the authors emphasize the beneficial effect of both $\mathrm{Zn}^{2+}$ and $\mathrm{Cu}^{2+}[30,36]$, which was exerted mainly in barley at the initial culture phase during pretreatment and anther/microspore culture. Thus, these findings confirm that the switch of the microspore developmental program from the gametophytic to the sporophytic pathway giving rise to haploid embryos occurs in the earliest stages of androgenesis [49].

In contrast to zinc, in the present study, the addition of $\mathrm{AgNO}_{3}$ to the induction medium had an advantageous impact on oat anther response. Compared to the control, the enhanced callus production was obtained after supplementation with $\mathrm{AgNO}_{3}$ at both of the tested concentrations. The higher frequency of callus induction, observed in both cultivars, suggests that the addition of silver nitrate inhibits the ethylene production, acting as a 
promoter of regeneration processes in oat anthers. However, the concentration of $25 \mu \mathrm{M}$ initiated a better response in relation to ELS formation and GP regeneration. In a previous study on white cabbage, the successful induction of regenerative processes was observed after the application of $50 \mu \mathrm{M} \mathrm{AgNO}$, demonstrating a high frequency (58.8\%) of callus formation [50]. Likewise, Wu et al. [51] observed that supplementing culture media with silver nitrate stimulates the embryogenesis of immature wheat embryos, but only up to a concentration of $60 \mu \mathrm{M}$, after which it was toxic and lowered embryogenic calli formation. On the contrary, Orłowska and Bednarek [52] reported that barley plant regeneration occurs under the highest $\mathrm{AgNO}_{3}(60 \mu \mathrm{M})$ concentration used in this experiment. Our results support the theory of Cristea et al. [50], which suggested that the increase in anther regeneration of cabbage genotypes cultivated on media supplemented with $\mathrm{Ag}^{+}$ions is due to the intervention of silver nitrate as a suppressor of ethylene. Furthermore, in our study $\mathrm{AgNO}_{3}$ promoted yellow compact callus induction, which was not observed in the case of the white friable structure. Yellow compact calluses were embryogenic, producing ELS and embryos, while white friable calluses did not regenerate. The present results are in agreement with earlier studies by Morris and DeMacon [53] stating that the friable wheat callus is of poor quality with a low potential for regeneration. It is considered that poor callus quality might be one of the reasons behind the poor haploid plant regeneration. Therefore, media modifications should target the production of embryogenic calluses with a good regeneration ability rather than simply inducing prolific calluses from which regeneration would not be possible [54].

In conclusion, our results demonstrate that the adjustment of copper, zinc, and silver concentrations in media may be a key point in promoting androgenesis in oat, especially when $\mathrm{CuSO}_{4}$ is added to the pretreatment medium or when $\mathrm{AgNO}_{3}$ is added to the induction medium. As oat androgenesis is still strongly cultivar-dependent, adjusting media components and their concentrations seems to be the only way to significantly improve the efficiency of this method.

\section{Materials and Methods}

\subsection{Donor Plant Growth}

Oat (Avena sativa L.) cultivars 'Bingo' and 'Chwat' were used as sources of anthers for studying androgenic abilities. Seeds of each genotype were sown singly into a mixture of soil and sand (3:1 (v/v) in 3 L pots. Twenty donor plants of each cultivar were grown under controlled conditions at $21 / 17^{\circ} \mathrm{C}$ day/night with a $16 \mathrm{~h}$ photoperiod, in a greenhouse under natural (solar) light during the day and sodium lamps between 6 and 8 a.m. and additionally between 6 and 10 p.m. on cloudy days. Plants were fertilized with a liquid Hoagland and Arnon [55] medium once a week.

\subsection{Pretreatment, Isolation, and Incubation}

Tillers of $c v$. 'Bingo' and 'Chwat' were cut when the panicle was inside the leaf sheath and the distance from the base of the flag leaf to the penultimate leaf was a maximum of $4.0 \mathrm{~cm}$ [6]. Oat tillers were covered with aluminum bags and pretreated in Hoagland and Arnon [55] liquid medium alone (control) and with the addition of $\mathrm{Cu}^{2+}, \mathrm{Zn}^{2+}$, or $\mathrm{Ag}^{+}$ions for 2 weeks at $4{ }^{\circ} \mathrm{C}$, and then kept at $32{ }^{\circ} \mathrm{C}$ for $24 \mathrm{~h}$. Next, the panicles were disinfected in $70 \%(\mathrm{v} / \mathrm{v})$ ethanol $(1 \mathrm{~min})$, then in a $2.5 \%(\mathrm{w} / \mathrm{v})$ solution of calcium hypochlorite $(65 \%$ $\mathrm{Ca}(\mathrm{OCl})_{2}(7 \mathrm{~min})$, and triple washed with sterile water [6]. For ELS induction, anthers were aseptically isolated on W14 medium [25] with $2.0 \mathrm{mgL}^{-1}$ 2,4-dichlorophenoxyacetic acid (2,4-D), $0.5 \mathrm{mgL}^{-1}$ kinetin, $9 \%$ maltose, and $0.6 \%$ agar (control), with the addition of $\mathrm{Cu}^{2+}$, $\mathrm{Zn}^{2+}$, or $\mathrm{Ag}^{+}$ions. The media $\mathrm{pH}$ was adjusted to 6.0 before autoclaving $\left(120^{\circ} \mathrm{C}, 20 \mathrm{~min}\right)$. $\mathrm{Cu}^{2+}, \mathrm{Zn}^{2+}$, or $\mathrm{Ag}^{+}$ions were added to the media in salt form in two concentrations: $\mathrm{CuSO}_{4} \times 5 \mathrm{H}_{2} \mathrm{O}(10$ or $20 \mu \mathrm{M}), \mathrm{ZnSO}_{4} \times 7 \mathrm{H}_{2} \mathrm{O}(90$ or $180 \mu \mathrm{M})$ and $\mathrm{AgNO}_{3}(25$ or $50 \mu \mathrm{M})$. The arrangement of the experiment is presented in Table 3. All the salt stock solutions were filter-sterilized and added to the autoclaved medium at about $50{ }^{\circ} \mathrm{C}$. Anther cultures were incubated in the dark at $28 \pm 1^{\circ} \mathrm{C}$. Embryogenic structures were observed under a 
light microscope (SMZ 1500, Nikon, Tokyo, Japan) and the efficiency of androgenesis was determined as the number of calluses, ELS, and GPs obtained from 100 anthers.

Table 3. The arrangement of the experiment.

\begin{tabular}{|c|c|}
\hline $\begin{array}{c}\text { Tillers Pretreatment } \\
2 \text { Weeks at } 4{ }^{\circ} \mathrm{C} \text { and } 24 \mathrm{~h} \text { at } 32{ }^{\circ} \mathrm{C}\end{array}$ & $\begin{array}{l}\text { Incubation of Anther Cultures } \\
\text { at } 28^{\circ} \mathrm{C} \text { in Darkness }\end{array}$ \\
\hline $50 \%$ Hoagland's liquid medium & $\begin{array}{l}\text { W14 medium with addition of 2,4-D }\left(2.0 \mathrm{mgL}^{-1}\right) \text {, } \\
\text { kinetin }\left(0.5 \mathrm{mgL}^{-1}\right) \text { and: } \\
10 \mu \mathrm{M} \mathrm{CuSO}_{4} \times 5 \mathrm{H}_{2} \mathrm{O} \\
20 \mu \mathrm{M} \mathrm{CuSO}_{4} \times 5 \mathrm{H}_{2} \mathrm{O} \\
90 \mu \mathrm{M} \mathrm{ZnSO} 4 \times 7 \mathrm{H}_{2} \mathrm{O} \\
180 \mu \mathrm{M} \mathrm{ZnSO} \mathrm{Zn}_{4} \times 7 \mathrm{H}_{2} \mathrm{O} \\
25 \mu \mathrm{M} \mathrm{ANNO}_{3} \\
50 \mu \mathrm{M} \mathrm{ANNO}_{3}\end{array}$ \\
\hline $\begin{array}{l}50 \% \text { Hoagland's liquid medium with } \\
\text { addition of: } \\
10 \mu \mathrm{M} \mathrm{CuSO}_{4} \times 5 \mathrm{H}_{2} \mathrm{O} \\
20 \mu \mathrm{M} \mathrm{CuSO}_{4} \times 5 \mathrm{H}_{2} \mathrm{O} \\
90 \mu \mathrm{M} \mathrm{ZnSO} 4 \times 7 \mathrm{H}_{2} \mathrm{O} \\
180 \mu \mathrm{M} \mathrm{ZnSO}_{4} \times 7 \mathrm{H}_{2} \mathrm{O} \\
25 \mu \mathrm{MgNO}_{3} \\
50 \mu \mathrm{M} \mathrm{AgNO}_{3}\end{array}$ & $\begin{array}{l}\text { W14 medium with addition of 2,4-D }\left(2.0 \mathrm{mgL}^{-1}\right) \\
\text { and kinetin }\left(0.5 \mathrm{mgL}^{-1}\right)\end{array}$ \\
\hline
\end{tabular}

\subsection{Regeneration and Doubling the Number of Chromosomes}

Developed GPs were transferred into Magenta boxes containing solidified ( $0.6 \%$ agar) MS medium [56] with half the original concentrations, without growth regulators. They were maintained at $21 \pm 2{ }^{\circ} \mathrm{C}$ and a light intensity of $60 \mu \mathrm{mol} \mathrm{m}^{-2} \mathrm{~s}^{-1}(16 / 8 \mathrm{~h} \mathrm{light} /$ dark $)$. Subsequently, GPs were acclimated to ex vitro conditions by transferring them into boxes with moist perlite and then to the soil. The chromosome doubling procedure was carried out according to Warchoł et al. [10].

\subsection{Statistical Analysis}

The significance of differences in mean values was analyzed using a two-way analysis of variance (ANOVA).

The experiment was performed with the completely randomized design model application for the analysis of variance. The Duncan's multiple range test implemented in the statistical package STATISTICA 10.0 (Stat-Soft, Inc., Tulsa OK Oklahoma, USA) was applied to detect significant differences among cultivars, pretreatment, and induction media. Significant differences between treatments at $p<0.05$ were marked with different letters.

Author Contributions: Conceptualization, M.W., E.S.; methodology, M.W., E.S.; validation, I.M.; formal analysis, M.W., K.J., E.S.; investigation, E.S., M.W., K.D., I.C.-M., I.M., K.J., K.K.; resources, M.W.; data curation, M.W., E.S.; writing—original draft preparation, M.W., E.S., K.J.; writing—review and editing, M.W., E.S., K.J.; visualization, K.J., K.K.; supervision, M.W. All authors have read and agreed to the published version of the manuscript.

Funding: This research was funded by the Franciszek Górski Institute of Plant Physiology, Polish Academy of Sciences.

Institutional Review Board Statement: Not applicable.

Informed Consent Statement: Not applicable.

Data Availability Statement: All data is contained within the article. The datasets used and analyzed during the current study are available from the corresponding author on reasonable request.

Conflicts of Interest: The authors declare no conflict of interest. 


\section{References}

1. Seguí-Simarro, J.M. Androgenesis Revisited. Bot. Rev. 2010, 76, 377-404. [CrossRef]

2. Jähne, A.; Lörz, H. Cereal microspore culture. Plant Sci. 1995, 109, 1-12. [CrossRef]

3. Forster, B.P.; Heberle-Bors, E.; Kasha, K.J.; Touraev, A. The resurgence of haploids in higher plants. Trends Plant Sci. 2007, 12, 368-375. [CrossRef]

4. Sidhu, P.K.; Davies, P.A. Regeneration of fertile green plants from oat isolated microspore culture. Plant Cell Rep. 2009, 28 , 571-577. [CrossRef]

5. Kiviharju, E.; Moisander, S.; Tanhuanpää, P. Oat Anther Culture and Use of DH-Lines for Genetic Mapping. In Oat. Methods in Molecular Biology; Gasparis, S., Ed.; Humana Press: New York, NY, USA, 2017; Volume 1536, pp. 71-93.

6. Warchoł, M.; Czyczyło-Mysza, I.; Marcińska, I.; Dziurka, K.; Noga, A.; Kapłoniak, K.; Pilipowicz, M.; Skrzypek, E. Factors inducing regeneration response in oat (Avena sativa L.) anther culture. Vitr. Cell. Dev. Biol. Plant 2019, 55, 595-604. [CrossRef]

7. Sidhu, P.K.; Howes, N.K.; Aung, T.; Zwer, P.K.; Davies, P.A. Factors affecting oat haploid production following oat $\mathrm{x}$ maize hybridization. Plant Breed. 2006, 125, 243-247. [CrossRef]

8. Marcińska, I.; Nowakowska, A.; Skrzypek, E.; Czyczyło-Mysza, I. Production of double haploids in oat (Avena sativa L.) by pollination with maize (Zea mays L.). Cent. Eur. J. Biol. 2013, 8, 306-313. [CrossRef]

9. Nowakowska, A.; Skrzypek, E.; Marcińska, I.; Czyczyło-Mysza, I.; Dziurka, K.; Juzoń, K.; Cyganek, K.; Warchoł, M. Application of chosen factors in the wide crossing method for the production of oat doubled haploids. Open Life Sci. 2015, 10, 112-118. [CrossRef]

10. Warchoł, M.; Skrzypek, E.; Nowakowska, A.; Marcińska, I.; Czyczyło-Mysza, I.; Dziurka, K.; Juzoń, K.; Cyganek, K. The effect of auxin and genotype on the production of Avena sativa L. doubled haploid lines. Plant Growth Regul. 2016, 78, 155-165. [CrossRef]

11. Ishii, T.; Tanaka, H.; Eltayeb, A.E.; Tsujimoto, H. Wide hybridization between oat and pearl millet belonging to different subfamilies of Poaceae. Plant Reprod. 2013, 26, 25-32. [CrossRef]

12. Kiviharju, E.; Moisander, S.; Laurila, J. Improved green plant regeneration rates from oat anther culture and the agronomic performance of some DH lines. Plant Cell Tissue Organ Cult. 2005, 81, 1-9. [CrossRef]

13. Skrzypek, E.; Czyczyło-Mysza, I.; Marcińska, I.; Wędzony, M. Prospects of androgenetic induction in Lupinus spp. Plant Cell. Tissue Organ Cult. 2008, 94, 131-137. [CrossRef]

14. Germanà, M.A. Haploids and Doubled Haploids in Fruit Trees. In Advances in Haploid Production in Higher Plants; Touraev, A., Forster, B.P., Jain, S.M., Eds.; Springer: Dordrecht, The Netherlands, 2009; pp. 241-263.

15. Ferrie, A.M.R.; Irmen, K.I.; Beattie, A.D.; Rossnagel, B.G. Isolated microspore culture of oat (Avena sativa L.) for the production of doubled haploids: Effect of pre-culture and post-culture conditions. Plant Cell Tissue Organ Cult. 2014, 116, 89-96. [CrossRef]

16. Islam, S.M.S.; Tuteja, N. Production of Abiotic Stress Tolerant Fertile Transgenic Plants using Androgenesis and Genetic Transformation Methods in Cereal Crops. In Crop Improvement Under Adverse Conditions; Tuteja, N., Gill, S., Eds.; Springer: New York, NY, USA, 2013; pp. 213-229.

17. Smykal, P.; Pechan, P.M. Stress, as assessed by the appearance of sHsp transcripts, is required but not sufficient to initiate androgenesis. Physiol. Plant 2000, 110, 135-143. [CrossRef]

18. De Cesaro, T.; Baggio, M.I.; Zanetti, S.A.; Suzin, M.; Augustin, L.; Brammer, S.P.; Iorczeski, E.J.; Milach, S.C.K. Haplodiploid androgenetic breeding in oat: Genotypic variation in anther size and microspore development stage. Sci. Agric. 2009, 66, 118-122. [CrossRef]

19. Kiviharju, E.; Puolimatka, M.; Saastamoinen, M.; Hovinen, S.; Pehu, E. The effect of genotype on anther culture response of cultivated and wild oats. Agric. Food Sci. 1998, 7, 409-422. [CrossRef]

20. Kiviharju, E.; Pehu, E. The effect of cold and heat pretreatments on anther culture response of Avena sativa and A. sterilis. Plant Cell Tissue Organ Cult. 1998, 54, 97-104. [CrossRef]

21. Kiviharju, E.M.; Tauriainen, A.A. 2,4-Dichlorophenoxyacetic acid and kinetin in anther culture of cultivated and wild oats and their interspecific crosses: Plant regeneration from A. sativa L. Plant Cell Rep. 1999, 18, 582-588. [CrossRef]

22. Kiviharju, E.; Puolimatka, M.; Saastamoinen, M.; Pehu, E. Extension of anther culture to several genotypes of cultivated oats. Plant Cell Rep. 2000, 19, 674-679. [CrossRef]

23. Ślusarkiewicz-Jarzina, A.; Ponitka, A. The effect of physical medium state on anther culture response in polish cultivated oat (Avena sativa L.). Acta Biol. Crac. Ser. Bot. 2007, 49, 27-31.

24. Kaushal, L.; Balachandran, S.M.; Ulaganathan, K.; Shenoy, V. Effect of Culture Media on Improving Anther Culture Response of Rice (Oryza sativa L.). Int. J. Agric. Innov. Res. 2014, 3, 218-224.

25. Ouyang, J.W.; Jia, S.E.; Zhang, C.; Chen, X.; Fen, G. A New Synthetic Medium (W14) for Wheat Anther Culture. In Annual Report 1987-1988; Institute of Genetics, Academia Sinica: Beijing, China, 1989; pp. 91-92.

26. Xingzhi, W.; Han, H. The effect of Potato II medium for triticale anther culture. Plant Sci. Lett. 1984, 36, 237-239. [CrossRef]

27. Dahleen, L.S. Improved plant regeneration from barley callus cultures by increased copper levels. Plant Cell Tissue Organ Cult. 1995, 43, 267-269. [CrossRef]

28. Jacquard, C.; Nolin, F.; Hécart, C.; Grauda, D.; Rashal, I.; Dhondt-Cordelier, S.; Sangwan, R.S.; Devaux, P.; Mazeyrat-Gourbeyre, F.; Clément, C. Microspore embryogenesis and programmed cell death in barley: Effects of copper on albinism in recalcitrant cultivars. Plant Cell Rep. 2009, 28, 1329-1339. [CrossRef] [PubMed] 
29. Jewell, A.W.; Murray, B.G.; Alloway, B.J. Light and electron microscope studies on pollen development in barley (Hordeum vulgare L.) grown under copper-sufficient and deficient conditions. Plant Cell Environ. 1988, 11, 273-281. [CrossRef]

30. Echavarri, B.; Soriano, M.; Cistué, L.; Vallés, M.P.; Castillo, A.M. Zinc sulphate improved microspore embryogenesis in barley. Plant Cell Tissue Organ Cult. 2008, 93, 295-301. [CrossRef]

31. Maksymiec, W. Effect of copper on cellular processes in higher plants. Photosynthetica 1998, 34, 321-342. [CrossRef]

32. Bueno, P.; Piqueras, A. Effect of transition metals on stress, lipid peroxidation and antioxidant enzyme activities in tobacco cell cultures. Plant Growth Regul. 2002, 36, 161-167. [CrossRef]

33. Sathyanarayana, B.N.; Varghese, D.B. Plant Tissue Culture: Practices and New Experimental Protocols; I.K. International Publishing House Pvt. Ltd.: New Delhi, India, 2007.

34. Purnhauser, L.; Gyulai, G. Effect of copper on shoot and root regeneration in wheat, triticale, rape and tobacco tissue cultures. Plant Cell Tissue Organ Cult. 1993, 35, 131-139. [CrossRef]

35. Oguchi, K.; Tanaka, N.; Komatsu, S.; Akao, S. Methylmalonate-semialdehyde dehydrogenase is induced in auxin-stimulated and zinc-stimulated root formation in rice. Plant Cell Rep. 2004, 22, 848-858. [CrossRef] [PubMed]

36. Wojnarowiez, G.; Jacquard, C.; Devaux, P.; Sangwan, R.S.; Clément, C. Influence of copper sulfate on anther culture in barley (Hordeum vulgare L.). Plant Sci. 2002, 162, 843-847. [CrossRef]

37. Makowska, K.; Oleszczuk, S.; Zimny, J. The effect of copper on plant regeneration in barley microspore culture. Czech J. Genet. Plant Breed. 2017, 53, 17-22. [CrossRef]

38. Hossain, B.; Hirata, N.; Nagatomo, Y.; Akashi, R.; Takaki, H. Internal Zinc Accumulation Is Correlated with Increased Growth in Rice Suspension Culture. J. Plant Growth Regul. 1997, 16, 239-243. [CrossRef]

39. Kumar, V.; Parvatam, G.; Ravishankar, G.A. $\mathrm{AgNO}_{3}-\mathrm{A}$ potential regulator of ethylene activity and plant growth modulator. Electron. J. Biotechnol. 2009, 12. [CrossRef]

40. Naik, S.K.; Chand, P.K. Silver nitrate and aminoethoxyvinylglycine promote in vitro adventitious shoot regeneration of pomegranate (Punica granatum L.). J. Plant Physiol. 2003, 160, 423-430. [CrossRef]

41. Kaur, A.; Kumar, A. The Effect of Gelling agent, medium $\mathrm{pH}$ and silver nitrate on adventitious shoot regeneration in Solanum tuberosum. bioRxiv 2020, 1-15. [CrossRef]

42. Lentini, Z.; Reyes, P.; Martínez, C.P.; Roca, W.M. Androgenesis of highly recalcitrant rice genotypes with maltose and silver nitrate. Plant Sci. 1995, 110, 127-138. [CrossRef]

43. Huang, X.Q.; Wei, Z.M. High-frequency plant regeneration through callus initiation from mature embryos of maize (Zea mays L.). Plant Cell Rep. 2004, 22, 793-800. [CrossRef]

44. Plus, J.; George, L.; Eapen, S.; Rao, P.S. Enhanced plant regeneration in pearl millet (Pennisetum americanum) by ethylene inhibitors and cefotaxime. Plant Cell Tissue Organ Cult. 1993, 32, 91-96. [CrossRef]

45. Castillo, A.M.; Egaña, B.; Sanz, J.M.; Cistué, L. Somatic embryogenesis and plant regeneration from barley cultivars grown in Spain. Plant Cell Rep. 1998, 17, 902-906. [CrossRef]

46. Shahvali-Kohshour, R.; Moieni, A.; Baghizadeh, A. Positive effects of cold pretreatment, iron source, and silver nitrate on anther culture of strawberry (Fragaria $\times$ ananassa Duch.). Plant Biotechnol. Rep. 2013, 7, 481-488. [CrossRef]

47. Niroula, R.K.; Bimb, H.P. Effect of Genotype and Callus Induction Medium on Green Plant Regeneration from Anther of Nepalese Rice Cultivars. Asian J. Plant Sci. 2009, 8, 368-374. [CrossRef]

48. Ghaemi, M.; Sarrafi, A.; Alibert, G. The effects of silver nitrate, colchicine, cupric sulfate and genotype on the production of embryoids from anthers of tetraploid wheat (Triticum turgidum). Plant Cell Tissue Organ Cult. 1994, 36, 355-359. [CrossRef]

49. Caredda, S.; Doncoeur, C.; Devaux, P.; Sangwan, R.S.; Clément, C. Plastid differentiation during androgenesis in albino and non-albino producing cultivars of barley (Hordeum vulgare L.). Sex. Plant Reprod. 2000, 13, 95-104. [CrossRef]

50. Cristea, T.O.; Leonte, C.; Brezeanu, C.; Brezeanu, M.; Ambarus, S.; Calin, M.; Prisecaru, M. Effect of AgNO 3 on androgenesis of Brassica oleracea L. anthers cultivated in vitro. AFRICAN J. Biotechnol. 2012, 11, 13788-13795. [CrossRef]

51. Wu, L.M.; Wei, Y.M.; Zheng, Y.L. Effects of silver nitrate on the tissue culture of immature wheat embryos. Russ. J. Plant Physiol. 2006, 53, 530-534. [CrossRef]

52. Orłowska, R.; Bednarek, P.T. Precise evaluation of tissue culture-induced variation during optimisation of in vitro regeneration regime in barley. Plant Mol. Biol. 2020, 103, 33-50. [CrossRef]

53. Morris, C.F.; DeMacon, V.L. Seed Dormancy and Tissue Culture Response in Wheat. Crop Sci. 1994, 34, 1324-1329. [CrossRef]

54. Silva, T.D. Indica rice anther culture: Can the impasse be surpassed? Plant Cell Tissue Organ Cult. 2010, 100, 1-11. [CrossRef]

55. Hoagland, D.R.; Arnon, D.I. The water-culture method for growing plants without soil. Circ. Calif. Agric. Exp. Stn. 1938, 347, 1-39.

56. Murashige, T.; Skoog, F. A revised medium for rapid growth and bio assays with tobacco tissue cultures. Physiol. Plant. 1962, 15, 473-497. [CrossRef] 